\title{
室内空気污染に対して高感度な酸化物半導体材料の探索
}

\author{
正 員 角崎 雅博（富山県工業技術センター） \\ 非会員 寺澤 孝志（富山県工業技術センタ一） \\ 正 員 谷野 克巳(富山目工業技術センター) \\ 非会員 龍山 智榮(富山大学)
}

\section{Exploration of Highly Sensitive Oxide Semiconductor Materials to Indoor-Air Pollutants.}

Masahiro Kadosaki, Member(Toyama Industrial Technology Center), Takashi Terasawa, Non-member(Toyama Industrial Technology Center), Katumi Tanino, Member(Toyama Industrial Technology Center), Chiei Tatuyama, Non-member(Toyama University)

Recently, the number of people taken ill in new house by indoor-air pollution, is steadily increasing. The phenomenon is what is called "sick house syndrome". Mostly it is caused by formaldehyde and VOC (Volatile Organic Compound) included in adhesive or paint. The development of a sensor system available to measure the indoor-air pollution level at high sensitivity is highly desired. The present work was carried out for searching highly sensitive oxide semiconductor materials to formaldehhyde, xylene, toluen. Among 23 metal oxides examined, $\mathrm{SnO}_{2}, \mathrm{WO}_{3}, \mathrm{In}_{2} \mathrm{O}_{3}, \mathrm{ZnO}, \mathrm{Co}_{3} \mathrm{O}_{4}$ and $\mathrm{Cr}_{2} \mathrm{O}_{3}$ showed relatively high sensitivity. Formaldehyde could be detected with excellent sensitivities by both $\mathrm{SnO}_{2}$ and $\mathrm{In}_{2} \mathrm{O}_{3}$ elements operated at $350{ }^{\circ} \mathrm{C}$. The high sensitivity to xylene and toluene was achieved by both $\mathrm{WO}_{3}$ and $\mathrm{In}_{2} \mathrm{O}_{3}$ elements operated at $350^{\circ} \mathrm{C}$. Further, the sensing property of $\mathrm{SnO}_{2}$ element to formaldehyde was extremely improved by the addition of $\mathrm{Ag}$, and that of $\operatorname{In}_{2} \mathrm{O}_{3}$ one to xylene or toluene was also largely improved by the addition of $\mathrm{Pd}$.

キーワード：半導体ガスセンサ、室内空気污染、シックハウス症候群、ホルムアルデヒド、キシレン、トルエン

\section{1. 緒 言}

近年、新築住宅、マンションあるいは任宅のリホーム後、 「目がチカチカする」「いやな二オイで気分が悪くなる」 などのいわゆる「シック八ウス症候群」 ${ }^{(1)(2)(3)}$ の人が增え、 大きな社会問題となっている。これは内装に用いられる建 材、塗料、接着剂、スプレーなどに含まれる化学物質が室 内で気化し、住人に健康障害を与える結果である。特に最 近の住宅は、乾式工法により大量の接着郕を使用すること、 高気密化・高断熱化指向により換気が悪くなっていること が、これらの「化学物質過敏症」の增加に拍車をかけてい る。この原因化学物質として、ホルムアルデヒドやVOC ${ }^{(4)}$ (揮発性有機化合物) が挙げられていて、物質により異な るが $1 \mathrm{ppb} \sim 1 \mathrm{ppm}$ 単位で発症し、日本では、ほほ 10 人に 1 人が化学物質過敏症を発症しているといわれる(3)。特にホ ルムアルデヒドが一番の要因とされ、これはロや鼻、皮覤 加ら体内に吸収されて、その量が我々の自然治痹力の範痼 を越えて蓄積されると、身体のバランスを崩しさまざまな
体調不良を引き起こすすしかしこの物質は接着剤として必 需品であると共に、防虫・防腐郕として效果も高く、コス トが安い上、汎用性が高いなどトータルで見ると有用な物 質であり、すぐには代用品が見つからないといわれている。 現在、ホルムアルデヒドの室内濃度はWHO（世界保健機 構）で基準值を $0.08 \mathrm{ppm}$ としており、日本では化学物質の 基準值は楥く、これまで合板に関して「0.5ppm 以下!（日 本農林規格）上ある程度であった。しかし、米国に遅れる $こ と 5$ 年、1997 年 6 月、厚生省が基準值を $0.08 \mathrm{ppm}$ と決め

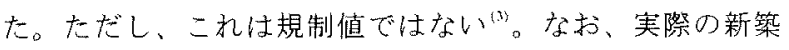
住宅の室内濃度の平均值は $0.2 \mathrm{ppm}$ といわれている

これまで、環境モニタリング用ガスセンサの研究 ${ }^{[5 /(6)}$ はN

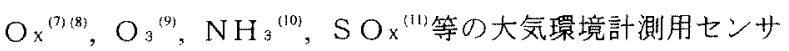
群と $\mathrm{CO}_{2}{ }^{(12)}, \mathrm{CO}^{(13)(14)}$ 等の室内環境計測センサ群に大きく 分類されているが、「シックハウス症候群」対策用センサ の報告例は見あたらない。これは、原因となるVOCガス の種類が非常に多いことにも起因していると思われる。し かし、我々は木材、建築住宅関係からの要望もあることか 
ら、「シックハウス症候群」の主な原因ガスであるホルム アルデヒドと、新築住宅に代表的なキシレン、トルエンを VOC の代表的污染源として選定し、これらを総合的に評価 する室内環境污染度評価センサの開発を行った。最初に、 酸化物半導体を中心としたセンサ材料を系統的に調べ、次 に高感度化のための第一ステップとして貴金属添加効果に ついて検討した。

\section{2. 実験方法}

\section{$2 \cdot 1$ センサの作製方法と構造}

センサは基板として厚さ $0.5 \mathrm{~mm}$ のアルミナ板を用い、250 メッシュの版を用いてスクリーン印刷により作成した ${ }^{(15)}$ 。 最初に一方の面に、Pt ペースト（田中貴金属工業）を用い て間隔 $0.5 \mathrm{~mm}$ の電極を印刷し、室温において 10 分間レベ

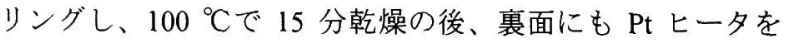

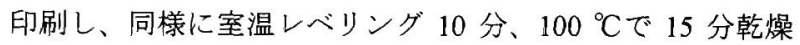
後、900 ${ }^{\circ} \mathrm{C}$ で 1 時間焼成した。その後 $\mathrm{Pt}$ 電極の上に、事前

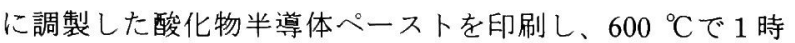
間焼成した。最後にPtリード線をPt 電極とPt ヒー夕に $\mathrm{Ag}$ ペーストを用いて固着し、600 ${ }^{\circ} \mathrm{C} て ゙ 1$ 時間焼成した。なお、 センサ材料は粒径約 1 数 $\mu \mathrm{m}$ の酸化物微粉末（高純度化 学研究所）に、エチルセルロースを主成分としたビヒクル

（田中貴金属工業）を加え、メノウ乳鉢にて十分混練しぺ 一スト化したものを用いた。作製したセンサの膜厚は約 30 umとした。
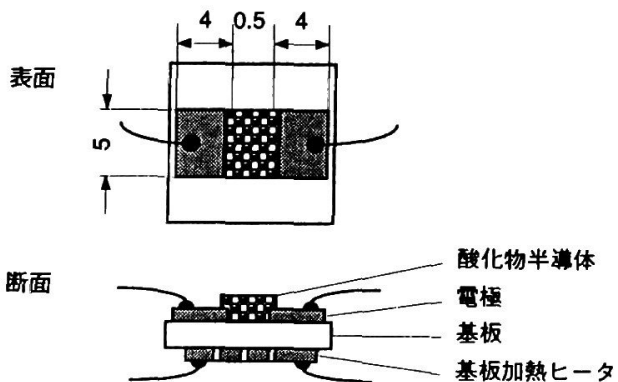

背面

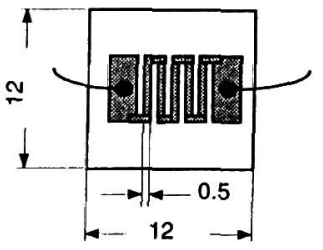

$(\mathrm{mm})$

\section{図 1. 試作した厚膜がスセンサの構造}

Fig.1 Schematic view of the structure of thick-film gas sensor

図 1 に試作したセンサの構造を示す。外形寸法は約 $10 x$ $10 \mathrm{~mm}$ 角である。また、図 2 は本研究で用いた酸化物半導 体粉末の焼成前の粒度分布を、レーザ粒度計により試薬の ラベル表示で粒径 $1 \mu \mathrm{m}$ の $\mathrm{ZnO}$ 粉末を測定した例である。
粒径 $0.2 \sim 1 \mu \mathrm{m}$ の範囲で分布していて、表示より小さめ に分布していた。また、平均粒径では $\mathrm{In}_{2} \mathrm{O}_{3}$ が一番小さく 約 $0.5 \mu \mathrm{m} 、 \mathrm{Co}_{3} \mathrm{O}_{5}$ が一番大きく約 $4 \mu \mathrm{m}$ であった。

図 3 は印刷、焼成後の酸化物の SEM 写真を示す。ZnO, $\mathrm{In}_{2} \mathrm{O}_{3}$ では殆どが 1 次粒子の集まりのようであったが、 $\mathrm{WO}_{3}$, $\mathrm{SnO}_{2}, \mathrm{Cr}_{2} \mathrm{O}_{3}, \mathrm{CO}_{3} \mathrm{O}_{5}$ では混練後も 1 次粒子の他、凝結粒子 や集団粒子と呼ばれる 2 次粒子が混ざった状態であった。 なお、焼成前後の粒子形状や粒径に大きな変化はなかった。

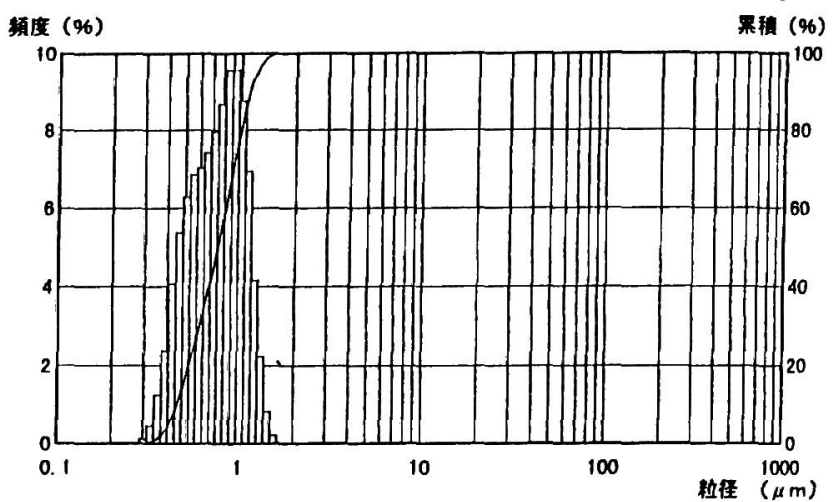

図 2. 使用した酸化物の粒度分布例 $(\mathrm{ZnO})$

Fig.2 Example of size distribution curve of metal oxide $(\mathrm{ZnO})$

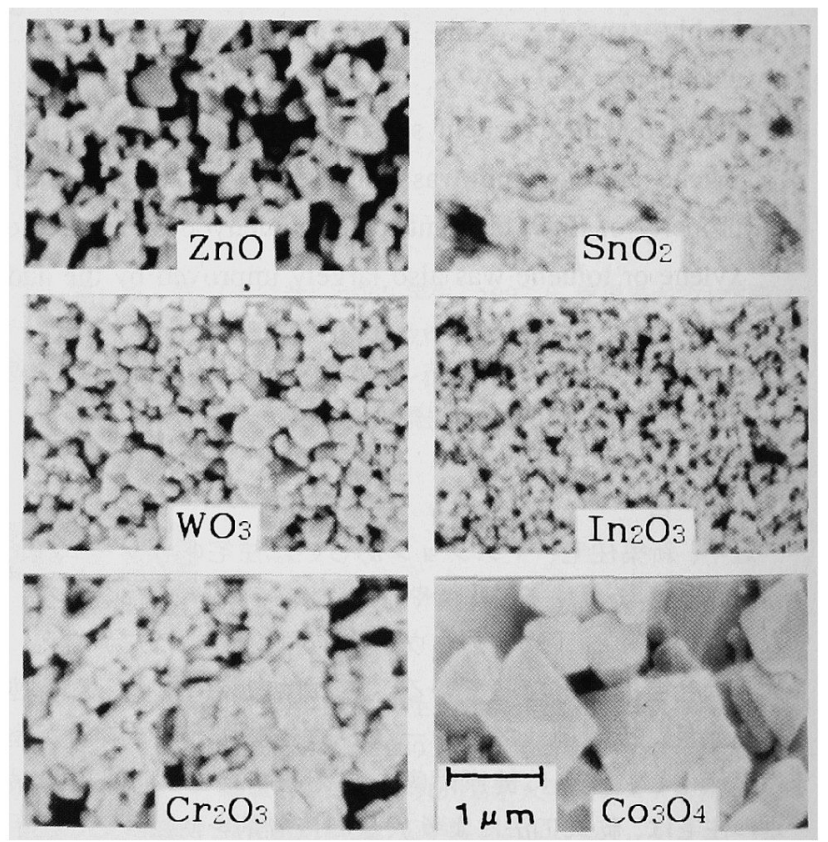

図 3. 焼結後の酸化物半導体表面

Fig.3 SEM images of several oxides sintered at $600{ }^{\circ} \mathrm{C}$ for $1 \mathrm{~h}$

\section{$2 \cdot 1$ 検出用ガスの作製とセンサ特性の評価法}

検出対象とした 3 種類のガス（ホルムアルデヒド、キシ レン、トルエン) 液体の特級試薬（和光純薬）加作成 した。ガス濃度 $\mathrm{C}(\%)$ は、分子量 $\mathrm{M}$ の物質 $\mathrm{M}(\mathrm{g})$ すなわち $1 \mathrm{~mol}$ が完全に気化すれば、0 ${ }^{\circ} \mathrm{C} 、 1$ 気圧 $(0.101 \mathrm{MPa})$ で 2.24 $\times 10^{-2}\left(\mathrm{~m}^{3}\right)$ の容積を占めることを利用した以下の気体の状態 
方程式より導かれるる

$C=\frac{X}{M} \times \frac{22.4}{V} \times \frac{273+t}{273} \times \frac{760}{p} \times 100 \quad \cdots(1)$

ここで、X $\mathrm{X}(\mathrm{g})$ は分子量 $\mathrm{M}$ の試料量、 $\mathrm{V}\left(\mathrm{m}^{3}\right)$ は容器の体積、 $\mathrm{p}(\mathrm{KPa})$ は気圧、t $\left({ }^{\circ} \mathrm{C}\right)$ は温度である。

液体の定量にはマイクロシリンジ及びマイクロピペット を用いた。また、目的濃度のガスの校正には簡便な方法と して市販の检知管 (ガステック社製)との比較より行った。 な拉、この検知管は、JISk0804により検知管の目盛り範囲 が $1 / 3$ 以上の濃度では土 $25 \%$ 、平均值では土 $15 \%$ の指示精 度が保証されている(16)。

図 4 はセンサを評価する装置の概要を示す。チャンバー は、内側が一辺 $0.4 \mathrm{~m}$ 、内容積 $64 \times 10^{-3}\left(\mathrm{~m}^{3}\right)$ の立方体であり、 センサは上面中央に队形状に取り付け、最大 12 個まで同一 ガス中で測定できる。上面のセンサ配列の外側に、測定ガ ス用の液体試料注入口、その直下に気化させるためのヒー

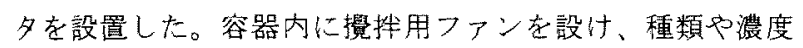
の違うガスを連続して測定することを可能にするために、 容器横に付けた排気口よりガスを強制的に排出できるよう にした。また、種類の異なるガスは、容器を水洗、乾燥後、 使用した。なお、センサ感度 $\alpha$ はn型酸化物に対しては、 空気中の抵抗 Rair とガス中の抵抗值 Rgas との比 Rair/Rgas で、p型に対しては逆にRgas/Rairで表した。

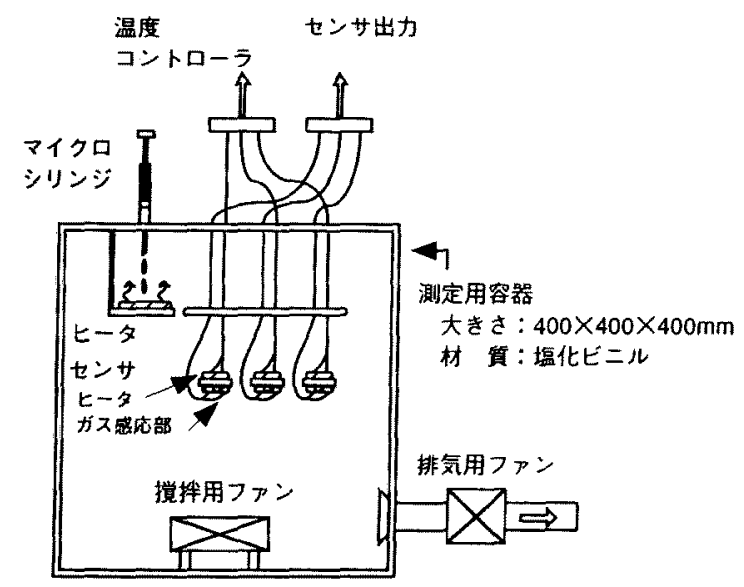

図 4.ガス感度測定の塞験装置

Fig.4 Experimental apparatus for measuring gas sensitivity.

図 5 はホルムアルデヒド、キシレンの(1)式による計算湍 度と、検知管で測定した濃度との比較結果である。図より、 検知管と計算で求めた濃度の誤差は最大 $20 \%$ と見積もられ る。ここで検知管自体 JIS によりさ $25 \%$ の誤差が許されて いることから、計算で求めたガス濃度はほぼ正確な值とな っていると考えられる。また、同一濃度において、作成条 件の異なる複数のセンサのガス感度を測定しようとする場
合、その個々のセンサの測定時間のズレから、チャンバー 内ガス濃度の減少による感度の减少が危惧される。

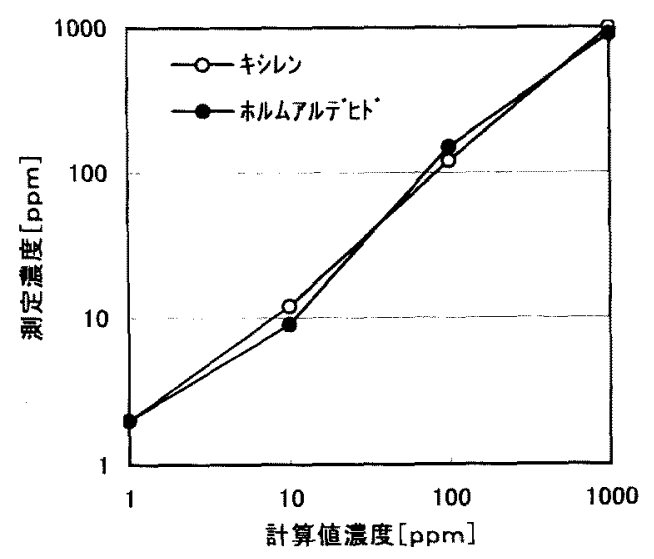

図 5.ガス濃度の計算值と測定値の比較

Fig.5 Comparison between calculated and measured values of gas concentration.

図 6 は 6 個のセンサを取り付け、10ppmのキシレン中に て動作させた場合の、容器中のガス濃度が時間と共に変化 する様子を調べたものである。センサが非動作時の場合は、 30 分経過してもガス濃度の減少は10\%程度であるが、セン サが動作時の場合、10 分で $10 \%$ 、30 分で $30 \%$ 程度濃度の 減少が見られる。二れは測定用センサを1個増やすごとに、 的 $0.16 \%$ /分のガス濃度の減少があることを意味する。こ のようにセンサ動作時に执いて、非動作時よりもガス䟴度 の減少量が多くなっている原因として、センサに印刷され た白金ヒータ、白金電極、酸化物等により、キシレンのセ ンサへの吸着、解離、分解が進んだことが推測される。そ のため、本研究に於けるガス濃度測定では上記のことを考 慮して、気化後最大 10 分以内に実験を行った。

なお、ガ不感度の測定は、素子温度 (Top) $350{ }^{\circ} \mathrm{C}$ 、相対湿 度 $60 \%$ の空気中にて 24 時間エージングした素子を用いた。

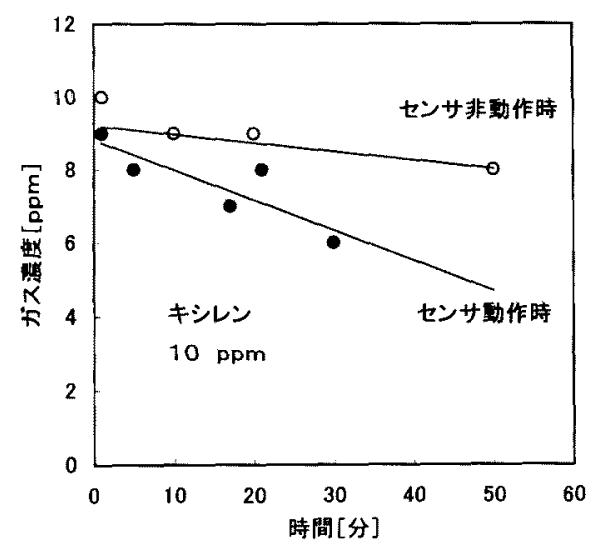

図 6. 容器内ガス濃度の時間変化

Fig. 6 Time dependence of gas concentrations in the experimental apparatus 


\section{3、実験結果及び考察}

\section{1 住宅污染ガス検知用センサ材料の探索}

3 種類の検知対象ガスに対して、ベース材料となる高感 度な酸化物を探すため、遷移金属を中心に 23 種類の酸化物 を用いた素子を作成し、素子温度 $350^{\circ} \mathrm{C}$ 、濃度 $1000 \mathrm{ppm}$ に おけるが感度を調べた。

图 7 は代表的な 18 種類の酸化物のホルムアルデヒド、キ シレン、トルエンに詨するセンサ感度測定の結果を $\mathrm{n}$ 型 (a) と $\mathrm{p}$ 型(b)に分類したグラフである。図のように、n 型酸化 物では $\mathrm{WO} 3, \mathrm{ZnO}, \mathrm{SnO}_{2}, \mathrm{In}_{2} \mathrm{O} 3$ の 4 種類が、どのガスに 対しても相対的に高感度であり、他の酸化物の感度は非常 に低かった。 $\mathrm{p}$ 型酸化物では $\mathrm{Co}_{3} \mathrm{O} 4, \mathrm{Cr}_{2} \mathrm{O} 3$ が比較的高感度 であった。そのため、本研究では上記 6 種類の酸化物につ いて更に検討した。

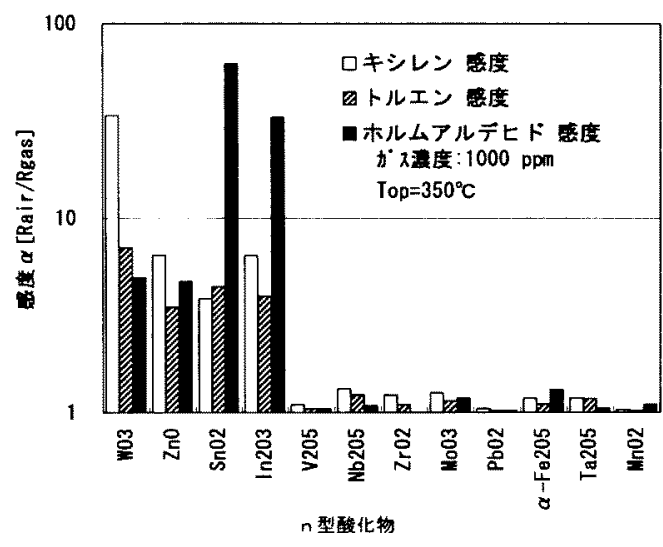

(a)

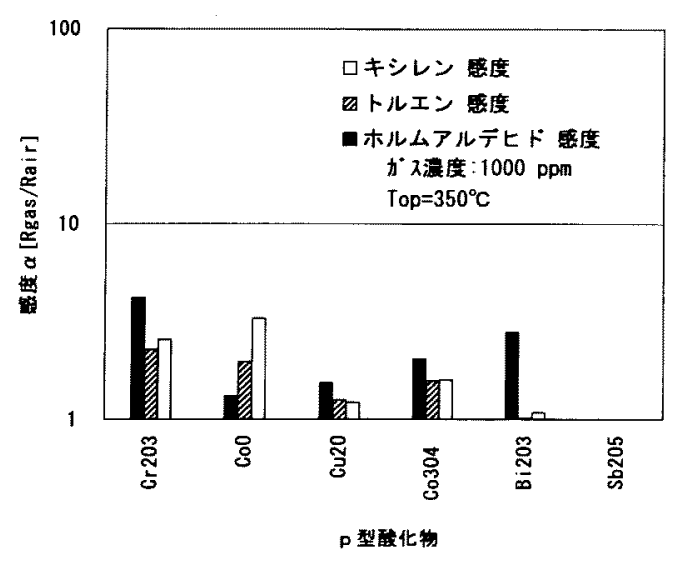

(b)

図 7. 各種金属酸化物の VOC カj

Fig. 7 Sensitivies of various oxide semiconductor materials to VOC gases, (a) n-type, (b) p-type.

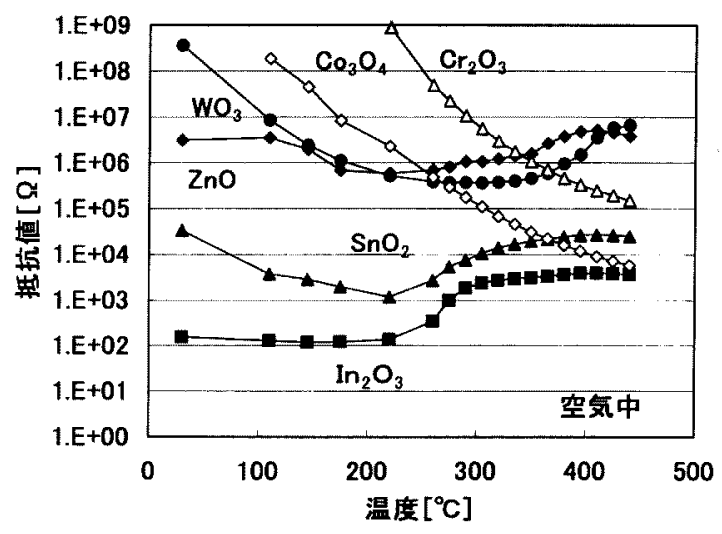

図 8. 空気中でのセンサ抵抗の温度依存性

Fig. 8 Temperature dependence of resistivities of several sensors in air

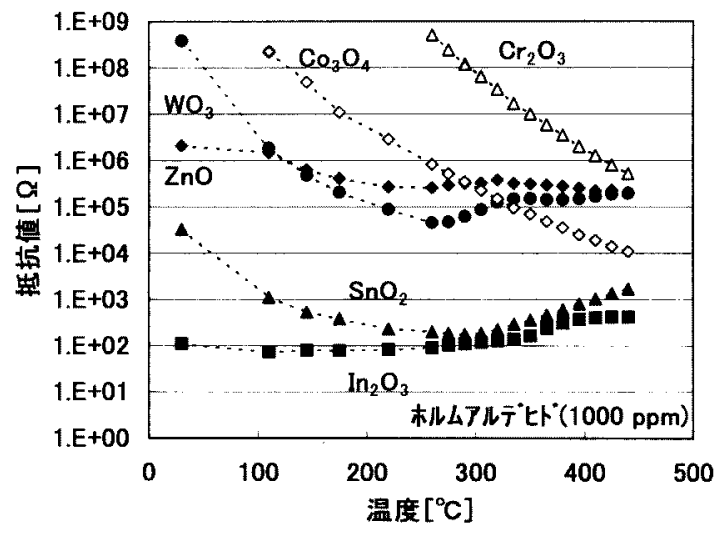

図 9 机ふアトデヒド1000 ppm 中でのセンサ抵抗の温度依存性 Fig.9 Temperature dependence of resistivities of several sensors in $1000 \mathrm{ppm}$ formaldehyde.

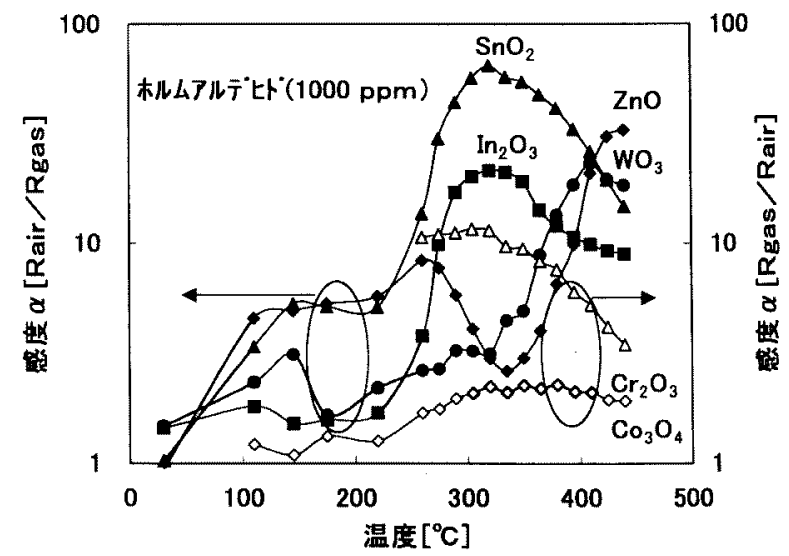

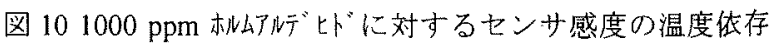
性

Fig.10 Temperature dependence of sensitivities to $1000 \mathrm{ppm}$ formaldehyde for several sensors . 


\subsection{6 種類の酸化物材料の抵抗值及びセンサ感度の温度 依存性}

上記 6 種の酸化物について、センサ温度範囲 $25^{\circ} \mathrm{C} \sim 450$ ${ }^{\circ} \mathrm{C}$ でのホルムアルデヒドに対するセンサ感度の温度依存性 について調べた。最初に上記酸化物の抵抗值の温度依存性 を図8に示す。6 種類の枋料上も室温から温度が上昇する に徉って、点久陷等の外因的な要因による電子又はホール の增加により抵抗健が減少し、n型酸化物 $\mathrm{SnO}_{2}, \ln 2 \mathrm{O}_{3}$, $\mathrm{ZnO}$ では約 $200^{\circ} \mathrm{C} 、 \mathrm{WO} 3$ では䄪 $300^{\circ} \mathrm{C}$ で最小になる。その 後、不純物、音響フォノン、光学フォノン等の散乱要因に より移動度が減少し、抵抗值が增加していく傾向にある。 また、2 種類の $\mathrm{p}$ 型酸化物の抵抗值は、この温度範囲では 単調に減少している。図 9 は 1000 ppm ホルムアルデヒド に対するセンサ抵抗の温度依存性であり、图8 とよく似た 傾向を示しつつも、n型では抵抗值が $1 \sim 2$ 析下がって、 逆に $\mathrm{p}$ 型では抵抗値が 1 桁弱上がっている。センサ感度は 図8、9より図10のようになり、各センサの最大感度を示 す温度は、 $\mathrm{ZnO}$ : 約 $420^{\circ} \mathrm{C} 、 W O 3$ : 約 $400^{\circ} \mathrm{C} 、 \mathrm{Co} 3 \mathrm{O} 4$ : 䄪 $350^{\circ} \mathrm{C}$ 、 $\mathrm{SnO} 2$ :約 $320^{\circ} \mathrm{C} 、 \mathrm{In} 2 \mathrm{O} 3$ 約 $320^{\circ} \mathrm{C} 、 \mathrm{Cr}_{2} \mathrm{O} 3$ 約 $300^{\circ} \mathrm{C}$ であった。

\section{$3 \cdot 33$ 種類の污染ガスに対する6種類の酸化物のガス濃度 依存性}

污染ガスであるホルムアルデヒド、キシレン、トルエン の3種類のガスに対して、センサ温度が $350{ }^{\circ} \mathrm{C}$ におけるガ ス溚度とセンサ感度の関係をそれぞれ図 $11(\mathrm{a}),(\mathrm{b}),(\mathrm{c})$ に示 す。雨対数プロットに执いて良好な直線性を示していると は言い難いものの、高感度化のための特別な尩理孝行わな い酸化物材料のみの場合の検出限界は、ホルムアルデヒド に対して $1 \mathrm{ppm}$ 前後、キシレン、トルエンに对しては数 ppm 程度であることが予想される。また、個別のガスに対する 感度を見ると、ホルムアルデヒドに対しては $\mathrm{SnO}_{2}, \quad \mathrm{In}_{2} \mathrm{O}_{3}$ が、キシレン、トルエンに対しては、WO3, In2O3 が最大感 度を示した。

\section{4 貴金属の添加効果}

センサ感度を问上させるには、粒径の制御("7)、キャリア 濃度の制御 ${ }^{(18)}$ 、酸塩基性の制御 ${ }^{(19)}$ 、酸化触媒活性の制御 ${ }^{(1)}$ (20)、酸素吸着の制御等いるいろ考えられるが、今回は酸化 触媒活性の制御に上る感度向上を期待し、平均粒径約 $1 \mu$ $\mathrm{m}$ で 7 種類の貴金属を $3 \mathrm{wt} \%$ 添加することによる効果を調 べた。ここで、3 粨類のガス濃度は各々500 ppm、センサ 温度住 $350^{\circ} \mathrm{C}$ 上し。

図 12 はホルムアルデヒドに感度の高かった $\mathrm{SnO} 2$ に貴金 属触媒を添加した例である。Ag を添加したセンサは、無添 加に比べて等気中の抵抗值 Rair が約 50 倍高くなり、また ホルムアルデヒドに対する感度は約 10 倍向上した。この $\mathrm{SnO}_{2} \sim の \mathrm{Ag}$ 添加による感度の増加に関しては、 Matsushima ら ${ }^{(20)}$ により「ガス霖囲気によりAg 粒子の酸化 状態が変わり $\mathrm{Ag} 2 \mathrm{O}$ に変化することにより、半導体の空間

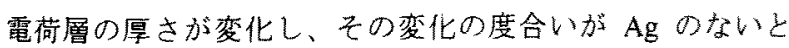

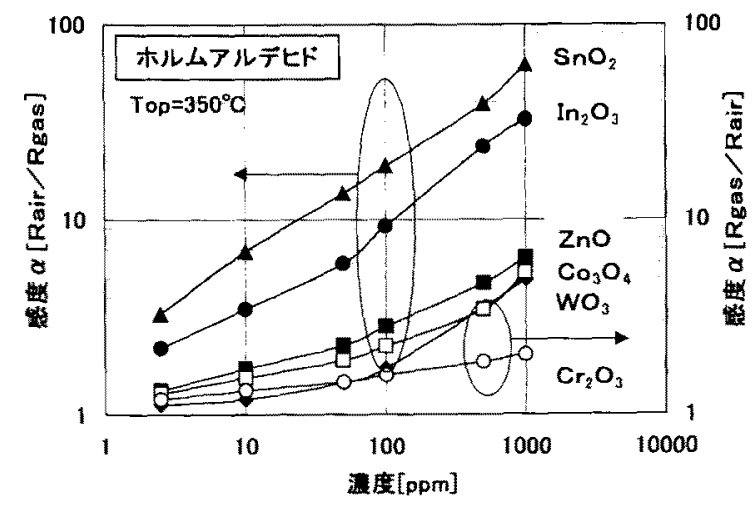

(a)

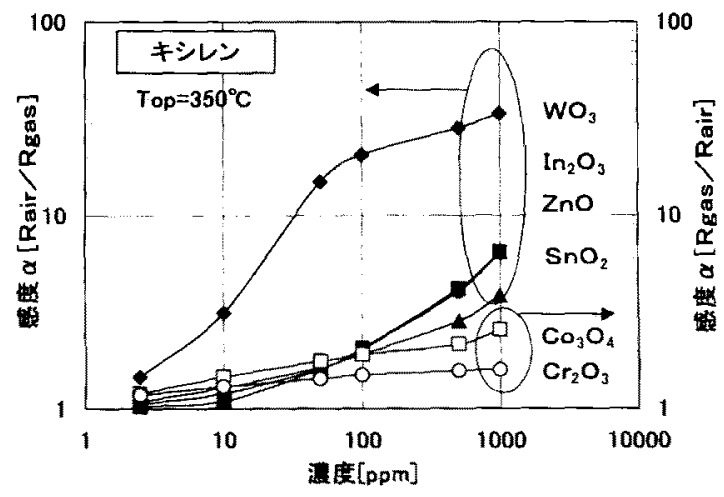

(b)

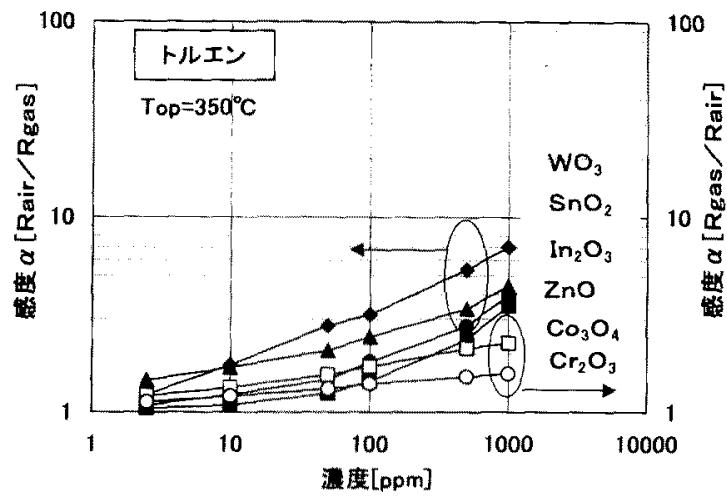

(c)

図 11,ガス濃度上センサ感度の関係

Fig.11 Dependence of sensitivities of selected sensors on concentration of three VOC gases, (a) formaldehyde, (b) xylene, (c) toluene

きよりも大きいためガス感度が增大する」いわゆる固接的 な電子授受により增感加行われる電子的相互作用による至 


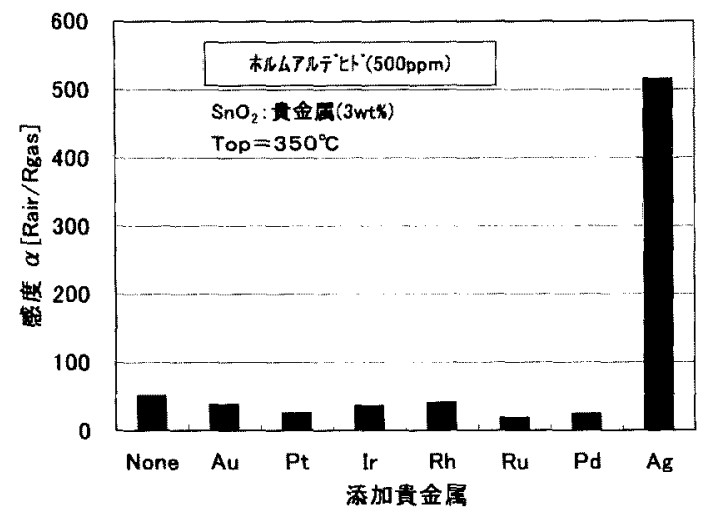

図 12. 貴金属を添加した $\mathrm{SnO}_{2}$ センサの机么アルデヒド感度 Fig. 12 Senstivities to $500 \mathrm{ppm}$ formaldehyde for $\mathrm{SnO}_{2}$-based sensors loaded with various noble metals.

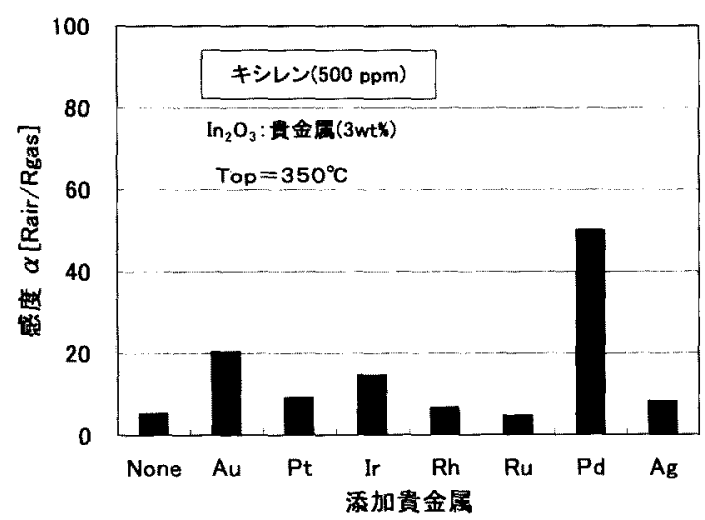

図 13. 貴金属を添加した $\ln _{2} \mathrm{O}_{3}$ センサのキシレン感度 Fig.13 Senstivities to $500 \mathrm{ppm}$ xylene for $\mathrm{In}_{2} \mathrm{O}_{3}$-based sensors loaded with various noble metals.

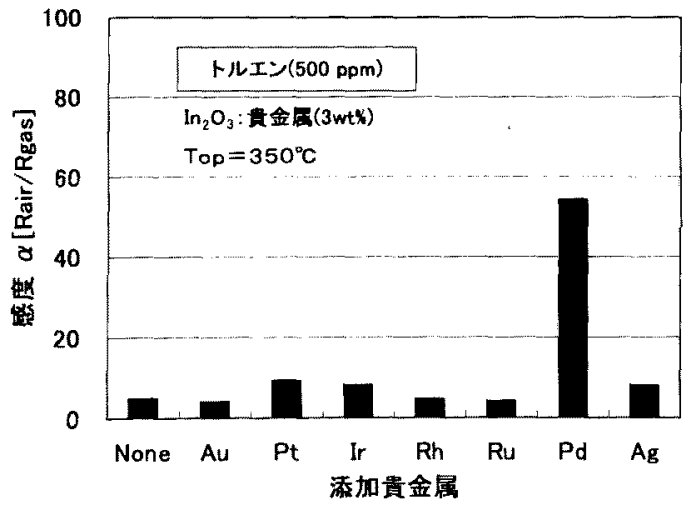

図 14. 貴金属を添加した $\mathrm{In}_{2} \mathrm{O}_{3}$ センサのトルエン感度

Fig. 14 Senstivities to $500 \mathrm{ppm}$ toluene for $\ln _{2} \mathrm{O}_{3}$-based sensors loaded with various noble metals.
のとされている。また、キシレン、トルエンに対してはWO3、 $\mathrm{In}_{2} \mathrm{O} 3 、 \mathrm{SnO}_{2}$ が高感度であったため、これらの酸化物に前 述の貴金属を添加したところ、In2O3にPdを添加すること により大幅な感度の向上が見られた。図13およぴ図14 は それぞれ、In2O3 に貴金属触媒を跃加したときの、キシレ ン、トルエンに対するセンサ感度を示したものである。こ の場合、無添加の $\mathrm{In} 2 \mathrm{O} 3$ と比べて Pd を添加してむ Rair は 殆ど変化しないが、両方のがスに対する感度は約 10 倍问上 した。これは接触酸化触媒としては比較的活性の小さな $\mathrm{In} 2 \mathrm{O} 3$ に、触媒活性の高い貴金属のPd を添加することで、 キシレン、トルエンのガスに対して酸化活性力が高まり增 感されたと考えられるもののその詳細は不明である。なお、 WO3, $\mathrm{SnO} 2$ もキシレン、トルェンに高感度であったため、 添加効果を調べたが、 In2O3 上同様、 $\mathrm{Pd}$ が最大添加効果を 示したものの双方とも 3 倍程度の増感に止まった。なお、 本研究では添加量を $3 w \%$ としたが、添加方法及び最適添加 量をさらに検討することにより、感度向上も期待される。

\section{4. 結 言}

「シックハウス症候群」の原因となる代表的な室内空気 污染物質であるホルムアルデヒド、トルエン、キシレンを 検知するため、23 種類の酸化物半導体のガス感度を調べた ところ、以下の新しい知見を得た。

(1) $\mathrm{n}$ 型では $\mathrm{ZnO}, \mathrm{SnO}_{2}, \mathrm{WO}, \mathrm{In}_{2} \mathrm{O} 3$ が、 $\mathrm{p}$ 型では $\mathrm{Co}_{3} \mathrm{O}_{4}$, $\mathrm{Cr}_{2} \mathrm{O}_{3} の$ 金属酸化物が高い慰度を示した。

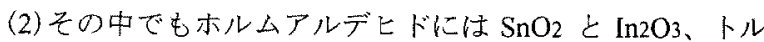
エンとキシレンには $\mathrm{WO}_{3}$ と $\mathrm{In}_{2} \mathrm{O}_{3}$ が高感度であった。

(3) 感度の良い6種類のセンサについてはホルムアルデヒド に最大感度を示古温度は以下のとおりであった。 $\mathrm{ZnO}$ : 約 $420^{\circ} \mathrm{C} 、 \mathrm{WO}$ : 約 $400{ }^{\circ} \mathrm{C} 、 \mathrm{Co} \mathrm{O} 4$ : 約 $350^{\circ} \mathrm{C} 、$ $\mathrm{SnO} 2 、 \mathrm{In} 2 \mathrm{O} 3$ :約 $320^{\circ} \mathrm{C} 、 \mathrm{Cr} 2 \mathrm{O} 3$ :約 $300^{\circ} \mathrm{C}$

（4）センサの高感度化を目指して7種類の貴金属を添加した ところ、ホルムアルデヒドには $\mathrm{SnO}_{2}$ に $\mathrm{Ag}$ を、またキ シレン、トルエンに対しては $\mathrm{In} 2 \mathrm{O} 3$ に $\mathrm{Pd}$ を添加した場 合にそれぞれ大幅な感度向上が見られた。

\section{謝 辞}

本研究を遂行するに際して数々の協力をしていただいた 北陸電気工業(侏) 角谷哲哉、三協アルミニウム工業俶 小島 理敬、コーセル侏 垣内由美子、富山県林業技術センター 長谷川益男各氏、そして多大なご助言、ご指導をいただき ました東京工業大学 鈴村暁男教授、名城大学 小川宏助教 授両先生に感謝いたします。

(平成 10 年 11 月 20 日受付, 平成 11 年 3 月 2 日再受付)

\section{文 献}

（1）小峰裕已：「住宅に打ける室内空気質に起因する健康 影響」, 住宅総合研究財団研究年報, NNo. 23,5-17（1996）

（2）岡屋武幸、井上雅雄、國吉惠梨子、星野五六、佐野孝雄、 
池田耕一：「特集 シックハウス 症候群にどう取り組 むか, 工業材料，45,8,102-123 (1997)

（3）日刊工業新聞社：「特集 化学物質過敏症は防げるか」， トリガー,17,2,6-36 (1998)

（4）松村俊郎：「室内空気污染の新たなる局面 VOCによ る室内空気污染の実態と防止策 $\mathrm{VOC}$ 上 $\mathrm{HCHO}$ の発 生源から健康影響、防止策」,ビルメインテナンス ,32,2,40-46 (1997)

（5）山添昇、酒井剛：「環境ガスセンサ研究の最近の動 向」, 電学論 $E, 118,2,60-63$ (1998).

（6）江頭誠、清水康博:「環境モニタリング用半導体ガス センサ」, 電学論 E, 118, 2, 64-67 (1998).

(7) 玉置純、長岡忠人、山本善史、松岡政夫 : $\left\ulcorner\mathrm{Co}_{3} \mathrm{O}_{4}-\mathrm{Fe}_{2} \mathrm{O}_{3}\right.$ 複合体を用いた酸化物半導体センサの NOx 検知特性」, 電学論,E,118,2,125-129 (1998)

(8) M.Akiyama, J.Tamaki, N.Miura and N.Yamazoe,

"Tungstem Oxide-Based Semiconductor Sensor for Detection of Nitrogen Oxide in Combustion Exhaut", Sensor and Actuators B, 13/14 619-620 (1993)

(9) T.Takada, K.Suzuki and M.Nakane "Highly sensitive ozone sensor", Sensors and Actuators B ,13/14, 404-407 (1993)

(10) T.Maekawa, J.Tamaki, N.Miura and N.Yamazoe, "Gold-Loaded Tungsten Oxide Sensor for Detection of Ammonia in Air", Chem. Lett., 1992, 639-642 (1992)

(11) Y.Yan, Y.Shimizu,N.Miura and N.Yamazoe"Highperformance solid-electlyte $\mathrm{SOx}$ sensor using $\mathrm{MgO}$ -stabilized zirconia tube and $\mathrm{Li}_{2} \mathrm{SO}_{4}-\mathrm{CaSO}_{4}-\mathrm{SiO}_{2}$ auxiliary phase", Sensors and Actuators B ,20, 81-87 (1993)

(12) N.Miura, S.Yao, Y.Shimizu and N.Yamazoe,"Carbon Dioxide Sensor Using Sodium Ion Conductor and Binary Carbonate Auxiliary Electorode"J.Electrochem.Soc., 139,5,1384 (1992)

（13）山浦弘之、玉置純、守屋浩二、三浦則雄、山添 昇 : 「表面修飾剤による酸化仦今゙ウム系素子のCO 検知特性 の改善」、電学論 E,118,2,100-105 (1998)

(14) H.Low, G.Sulz, M.Lacher, G.Kuhner, G.Uptmoor, H. Reiter and K.Steiner, "Thin-Film In-doped V-catalysed $\mathrm{SnO}_{2}$ Gas Sensors", Sensors and Actuators B ,9, 215-219 (1993)

（15）大藪多可志、大沢哲夫、黑部利次、「スクリーン印刷法に よる半導体 ( $\mathrm{SnO} 2$ 系) ガスセンサの感度特性, , 電子通 信学会論文誌, J-65C,8,615-621 (1982)

（16）光明理化学工業㑣)「有害ガス測定ハンドブック」 243-261 第 2 版 (1994)

（17）山添昇：「化学センサー材料と検知機構 半導体ガス センサー」, 日本金属学会会報, 29,8,627-632（1990）

(18) Y.Takano, Y.Miya, Y.Tachiyama, Y.Simizu and M. Egashira,"Improvement in Trimethylamine Sensitivity of $\mathrm{In}_{2} \mathrm{O}_{3}$ and $\mathrm{Cr}_{2} \mathrm{O}_{3}$ Sensors by Valency Control", Denki Kagaku, 58, 12, 1162-1168 (1990)
(19) S.Matsushima, T.Maekawa, J.Tamaki, N.Miura and N.Yamazoe. "Role of Additives on Alcohol Sensing by Semiconductor Gas Sensor", Chem. Lett.,1989, 845-848 (1989)

(20) S.Matsushima, Y.Teraoka, N.Miura and N.Yamazoe, "Electronic Interaction between Metal Additives and Tin Dioxide-Based Gas Sensors", Jpn.J.Appl.Phys., 27, 1798-1802 (1988)

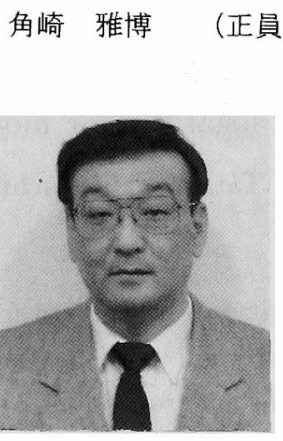

(正員) 1951 年 7 月 14 日生まれ。75年 富山大学大学院工学研究科電子工学 専攻（修士課程）卒。同年日本電装 (烌入社 83 年退社。現在、富山県工業 技術センター機械電子研究所副主幹 研究員。主に、機能性セラシックスを用い た薄膜、厚膜型が彵ン州の研究及び新 機能部品の研究に従事。電気学会、 電子情報通信学会、応用物理学会、 電気化学会、化学也研究会会員。

寺澤 孝志 (非会員) 1965 年 7 月 26 日生まれ。91 年富

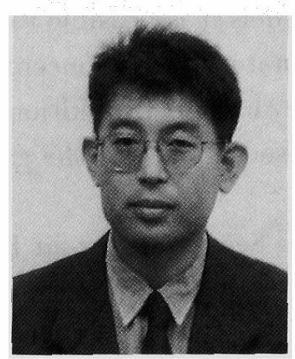
山大学大学院工学研究科電子工学専 攻 (修士課程) 卒。現在、富山県工 業技術センター機械電子研究所研究 員。主に、機能性高分子の機能発現 と評価法、デバイスへの応用に関する 研究に従事。応用物理学会、日本化 学会、高分子学会

谷野 克巳 (正員) 1946 年 3 月 17 日生まれ。69 年金沢

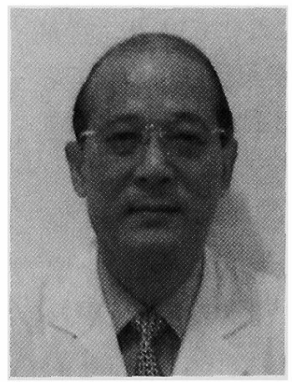
大学工学部電気工学科卒。現在、富 山県工業技術センター統括研究員。 主に、電気絶縁材料、導電材料、湿 式太陽電池、归方仏人二次電池等の開 発研究に従事。工学博士 (85 年)。技 術士 (83 年)。電気学会、回路実装学 会、材料技術研究協会、有機エレクトロニク 对料研究会会員。

龍山智榮 (非会員) 1943 年 4 月 16 生まれ。 72 年大阪

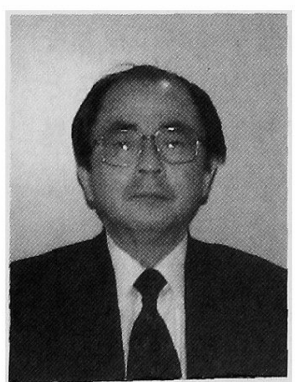
大学大学院工学研究科電子工学専攻 (博士課程) 卒。同年富山大学工学 部に勤務。現在、富山大学工学部電 気電子システム工学科教授。工学博 士。主に、分子線エピ多脑誠長、超 格子構造、半導体や金属の表面、界 面の研究に従事。電子情報通信学会、 忘用物理学会、米国 MRS 会員。 